\title{
Heavy Metals Contamination Through Industrial Effluent to Irrigation Water in Gadoon Amazai (Swabi) and Hayatabad (Peshawar) Pakistan
}

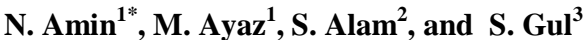 \\ ${ }^{1}$ Department of Chemistry, Abdul Wali Khan University Mardan, Pakistan \\ ${ }^{2}$ Department of Chemistry, University of Malakand, Chakdara, Dir (L), Pakistan \\ ${ }^{3}$ Department of Chemical Engineering, University of Engineering and Technology Peshawar, \\ Pakistan
}

Received 06 September 2013, accepted in final revised form 17 November 2013

\begin{abstract}
Industrial effluents mixed water used for irrigation in vegetable growing area was tested for its heavy metal contents using Atomic Absorption Spectrophotometry. Sixteen water samples from different industrial outlets were collected and analyzed for different physical and chemical parameters such as temperature, electrical conductivity, $\mathrm{pH}$, total dissolved solids and heavy metals, in the year 2011. The results showed $\mathrm{Cu}$ to be in the range of 0.102-0.260, Co 0.021-0.195, Fe 0.191-0.330, Pb 0.117-0.330, Cr 0.024-0.121, Mn 0.053$0.234, \mathrm{Zn} 0.090-0.165$ and $\mathrm{Ni}$ as $0.019-0.074 \mathrm{ppm}$. The overall metal concentration in the studied samples was in the order of $\mathrm{Fe}>\mathrm{Pb}>\mathrm{Cu}>\mathrm{Mn}>\mathrm{Co}>\mathrm{Zn}>\mathrm{Cr}>\mathrm{Ni}(\mathrm{p}<0.05)$. $\mathrm{pH}$ was in the range of 3.1-8.7 and electrical conductivity was 325 to $1515 \mathrm{~ms} / \mathrm{cm}$. As all values were found to be increasing towards pollution limits, industrial effluents need a continuous monitoring and proper management before their discharge in order to reduce the future hazards in reference to aquatic and human life.
\end{abstract}

Keywords: Industrial effluents; Irrigation water; Heavy metals; Pollution.

๑) 2014 JSR Publications. ISSN: 2070-0237 (Print); 2070-0245 (Online). All rights reserved.

doi: http://dx.doi.org/10.3329/jsr.v6i1.16336 J. Sci. Res. 6 (1), 111-124 (2014)

\section{Introduction}

Industries are the basic need for the development of a country and with the growing population, the need for establishing new industries is increasing. Industries manufacture useful products on one hand, but at the same time generate waste products, creating a number of environmental problems. The waste products may be in the form of solid, liquid or gas that lead to the creation of hazards, pollution and losses of energy. The wastes containing different pollutants and heavy metals are discharged into water and soil and ultimately pose a serious threat to human and ecosystem. The main contributors to the

*Corresponding author: noorulamin_xyz@yahoo.com 
water and soil pollution are the by-products of different industries such as textile, metal, dying chemicals, fertilizers, pesticides, cement, petrochemical, energy and power, leather, sugar processing, construction, steel, engineering and food processing industries. The rapid industrialization is accompanied both by direct and indirect adverse effects on environment [1]. Industrial development may result in the increasing generation of industrial effluents. If these effluents remain untreated, they may result in water sediment and soil pollution [2-3]. It has been reported that many industries discharge untreated effluents into river and only $10 \%$ industries surveyed had primary treatment ranging from oxidation tanks, sedimentation tanks in developing countries [4-6]. Heavy metals from industrial processes are of special concern because they produce chronic poisoning in aquatic animals [7-8].

Heavy metals are environmentally stable, non-biodegradable, and toxic to living organisms and tend to accumulate in plants and animals creating acute and chronic adverse effects on human health. They are introduced to the environment through different sources like combustion, extraction, agricultural runoff and transportation [9]. Heavy metals are considered as the priority toxic pollutants which ruthlessly limit the positive use of water for domestic and industrial application [10-11]. Regular use of water contaminated with heavy metals in cultivated fields leads to soil pollution and slowly make the soil enriched with heavy metals. It has been shown by different studies that the presence of heavy metals like $\mathrm{Fe}, \mathrm{Pb}, \mathrm{Hg}$ reduces the fertility of soil and agricultural output [12]. Certain heavy metals such as $\mathrm{Cu}, \mathrm{Fe}, \mathrm{Mn}, \mathrm{Ni}$ and $\mathrm{Zn}$ in control concentration, act as micronutrients for plants and micro-organisms while others like $\mathrm{Cd}, \mathrm{Pb}$ and $\mathrm{Cr}$ are harmful beyond a certain limits [13]. Selenium is essential for humans but becomes harmful or even toxic when its concentration exceeds certain level.

High levels of pollutants mainly organic matter in river water cause an increase in biological oxygen demand [14], chemical oxygen demand, total dissolved solids, total suspended solids and fecal coli form. They make water unsuitable for drinking, irrigation or any other use. There are trends in developing countries to use sewage effluent as fertilizer and this has gained much importance as it is considered as a source of organic matter and plant nutrients and serves as a good fertilizer [3]. Farmers are mainly interested in general benefits, like increased agriculture production, low cost water source, effective way of effluent disposal, source of nutrients, organic matters etc, but are not well aware of its harmful effects like heavy metal contamination of soils, crops and quality problems related to health. Research has shown that long term use of this sewage effluent for irrigation contaminates soil and crops to such an extent that it becomes toxic to plants and causes deterioration of soil [15]. This contains considerable amount of potentially harmful substances including soluble salts and heavy metals like $\mathrm{Fe}^{2+}, \mathrm{Cu}^{2+}, \mathrm{Zn}^{2+}, \mathrm{Mn}^{2+}, \mathrm{Ni}^{2+}$, and $\mathrm{Pb}^{2+}$. The addition of these heavy metals is therefore undesirable [3].

The aim of the present study was to evaluate various industrial effluents in District Swabi and Peshawar by various physiochemical parameters to predict possible danger to plants and human life and suggest necessary steps to be taken into account by industry to maintain the healthy environment. 


\section{Experimental}

\subsection{Study area}

Samples were collected from two industrial zones namely Peshawar and Gadoon Amazai District Swabi as given in Fig. 1. A number of industrial units are located in the adjacent areas. Most of the treated and untreated industrial effluents are being discharged into irrigating water. Several acres of agricultural land are irrigated by effluents mixed water and local farmers cultivate various types of crops of economic importance, including seasonal vegetables which uptake these metals. The waste water irrigation has been a common practice for many years in this area.
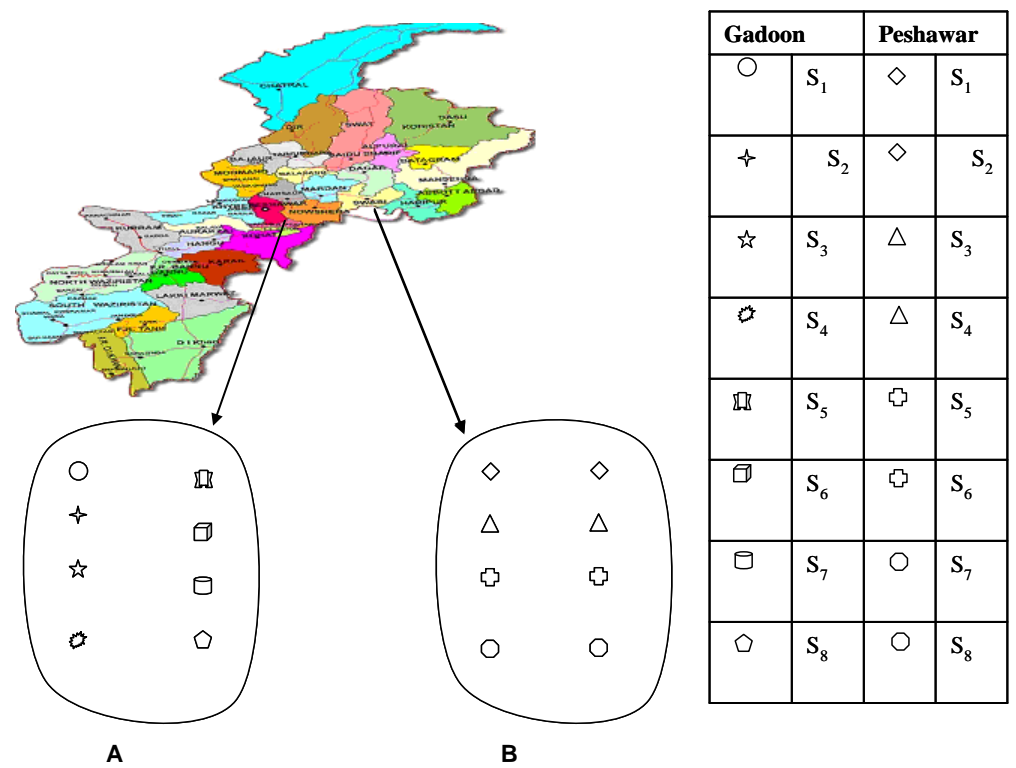

A

Fig. 1. Sampling map showing the location of samples from 1. Gadoon Amazai Industrial estate 2. Hayatabad Peshawar.

\subsection{Sample collection}

Total of 16 industrial effluents mixed irrigation water samples $(500 \mathrm{~mL})$ were taken in washed plastic bottles from different locations of Gadoon Amazai and Hayyatabad Peshawar in May-June 2011. The detail of sampling sites and their designation is given in Table 1. From Gadoon Amazai, samples were collected from Attock Chemical Industry, Sarhad Ion Steel Mill, M Ali Textile Mill, AAj Textile Mill, Amrat Cola (Pak Mineral Water Industry) Utman Ghee Industry, Amin Soap Industry and one sample from combined industrial water. In Hayyatabad Peshawar two samples each from different locations were collected from Khyber Match Box, Khyber Group of Precast, Khyber Medicine Laboratory and CSH Pharmaceutical (Pvt). 


\section{Heavy Metals Contamination}

Table 1. Sample identification and their location.

\begin{tabular}{lll}
\hline Industrial area & Sample ID & Sample location \\
\hline Gadoon amazai & $\mathrm{S}_{1}$ & Attock Chemical Industry \\
& $\mathrm{S}_{2}$ & Sarhad Iron Steel Mill \\
& $\mathrm{S}_{3}$ & M Ali Textile Mill \\
& $\mathrm{S}_{4}$ & AAj Textile Mill \\
& $\mathrm{S}_{5}$ & Amrat Cola (Pak mineral water industry) \\
& $\mathrm{S}_{6}$ & Utman Ghee Industry \\
& $\mathrm{S}_{7}$ & Amin Soap Industry \\
& $\mathrm{S}_{8}$ & Combined Industrial Water \\
Peshawar industrial & $\mathrm{S}_{1}$ & Khyber Match Box \\
& $\mathrm{S}_{2}$ & Khyber Match Box \\
& $\mathrm{S}_{3}$ & Khyber Group of Precast \\
& $\mathrm{S}_{4}$ & Khyber Group of Precast \\
& $\mathrm{S}_{5}$ & Khyber Medicine Laboratory \\
& $\mathrm{S}_{6}$ & Khyber Medicine Laboratory \\
& $\mathrm{S}_{7}$ & CSH Pharmaceutical (Pvt) \\
& $\mathrm{S}_{8}$ & CSH Pharmaceutical (Pvt) \\
\hline
\end{tabular}

Note: Samples have been collected from the outsides drain of plants.

\subsection{Analytical procedure}

The following analyses were carried out in the laboratory of the Department of Chemistry, Abdul Wali Khan University Mardan, Pakistan.

Physical parameters: Samples were assessed for various physiochemical parameters, like temperature using calibrated thermometer EPA 1998, $\mathrm{pH}$ using potentiometeric method, electrical conductivity and total dissolved solids.

Analysis of Trace metals: Trace metals such as $\mathrm{Cu}, \mathrm{Co}, \mathrm{Fe}, \mathrm{Pb}, \mathrm{Cr}, \mathrm{Mn}, \mathrm{Zn}$ and Ni were analyzed in all the samples using Atomic Absorption Spectrophotometer.

\subsection{Statistical analysis}

Data obtained during current study was analyzed statistically for mean, standard deviation, ANOVA and Duncan Multiple Range Test (DMRT) by using SPSS for windows, version 16.0 (SPSS Inc., Chicago, IL, USA). Probablity less than 0.05 was accepted as significant. 


\section{Results and Discussions}

To assess the pollution in the industrial effluents of the two study areas, the samples were analysed for various physiochemical parameters and the results were compared with values of National Environmental Quality Standards (NEQS), given in Table 2 [16].

Table 2. National environmental quality standards (NEQS, 2000).

\begin{tabular}{|c|c|c|c|c|c|c|c|c|c|c|}
\hline & $\mathrm{pH}$ & Temp. $\left({ }^{\circ} \mathrm{C}\right)$ & TDS & $\mathrm{Cu}$ & $\mathrm{Fe}$ & $\mathrm{Pb}$ & $\mathrm{Cr}$ & $\mathrm{Mn}$ & $\mathrm{Zn}$ & $\mathrm{Ni}$ \\
\hline $\begin{array}{l}\text { NEQS } \\
\text { limits }\end{array}$ & $6-10$ & 40 & 3500 & 1.0 & 2.0 & 0.5 & 1.0 & 1.5 & 5.0 & 1.0 \\
\hline
\end{tabular}

\section{1. $p H$}

The $\mathrm{pH}$ of the various industrial effluents ranged from 3.1 to 6.9 as shown in Table 3 . The effluents of Amrat cola (Pak mineral water industry) had the lowest $\mathrm{pH}$, while that of Utman Ghee industry had the highest $\mathrm{pH}$. Comparing with NEQS standards (Table 2) the $\mathrm{pH}$ value in the effluents of many industries was beyond the permissible limit and may have the adverse effects on the aquatic life and agriculture due to its high acidic nature. The variation in $\mathrm{pH}$ could be due to different types of chemicals discharged in the effluents. The permissible upper limit of $\mathrm{pH}$ in water used for irrigation purposes is 9 [3] which mean that the water having high $\mathrm{pH}$ under study creates no problem if it is used for irrigation purposes. A similar study carried out by Ahmed and Tanlo [7], showed the optimum $\mathrm{pH}$ for irrigation water ranged from 6.5 to 8.5 . The buffering capacity of soil tends to bring homeostasis and lower the $\mathrm{pH}$ of effluents applied [17]. The $\mathrm{pH}$ of effluents from Khyber Medicine Laboratory, Khyber Match Box and Amrat Cola was below the range set by NEQS (6 to 10) while the remaining sample showed $\mathrm{pH}$ within the range as given by NEQS.

\subsection{Electrical conductivity}

The electrical conductivities of the samples given in Table 3 varied from 325-1515 $\mu \mathrm{s} / \mathrm{cm}$. Electrical conductivity is a function of total dissolved solids (TDS) known as ion concentration, which determines the quality of water. The highest electrical conductivity was found in the sample collected from the spot where the effluents coming from all the industries of Gadoon combine and this demonstrated that soluble salts from all industries increased the concentration, resulting in the highest electrical conductivity. The lowest electrical conductivity $(325 \mu \mathrm{s} / \mathrm{cm})$ was found in the effluent discharged by Amin Soap Factory, which could be due to the fact that in saponification process no soluble salts are used. Actually for irrigation purposes the combined effluents are used in Gadoon area, which contains salts of different elements, some of which may be harmful for the vegetable, and ultimately for the health. 
Table 3. Physical parameters of industrial effluents.

\begin{tabular}{|c|c|c|c|c|c|}
\hline \multirow{2}{*}{$\begin{array}{l}\text { Industrial } \\
\text { area }\end{array}$} & \multirow[t]{2}{*}{ Sample ID } & \multicolumn{4}{|c|}{ Physical parameters } \\
\hline & & $\mathrm{pH}$ & $\mathrm{EC} \mu \mathrm{s} / \mathrm{cm}$ & Temp. $\left({ }^{\circ} \mathrm{C}\right)$ & TDS \\
\hline \multirow{8}{*}{$\begin{array}{l}\text { Gadoon } \\
\text { amazai } \\
\text { (swabi) }\end{array}$} & $\mathrm{S}_{1}$ & $6.3 \pm 0.13$ & $508 \pm 10.1$ & $32.2 \pm 0.64$ & $1000 \pm 40$ \\
\hline & $\mathrm{S}_{2}$ & $7.5 \pm 0.2$ & $802 \pm 16.5$ & $32.6 \pm 1.3$ & $1200 \pm 24.4$ \\
\hline & $\mathrm{S}_{3}$ & $7.8 \pm 0.17$ & $460 \pm 10.2$ & $32.9 \pm 1.8$ & $920 \pm 19.2$ \\
\hline & $\mathrm{S}_{4}$ & $7.6 \pm 0.14$ & $393 \pm 8.5$ & $33 \pm 2.1$ & $765 \pm 11.3$ \\
\hline & $\mathrm{S}_{5}$ & $3.1 \pm 0.1$ & $325 \pm 7.6$ & $33 \pm 1.5$ & $800 \pm 13.6$ \\
\hline & $\mathrm{S}_{6}$ & $8.7 \pm 0.21$ & $600 \pm 10.6$ & $33.2 \pm 2.4$ & $1330 \pm 22.4$ \\
\hline & $\mathrm{S}_{7}$ & $8.4 \pm 0.2$ & $862 \pm 8.3$ & $32.8 \pm 3.1$ & $1798 \pm 25$ \\
\hline & $\mathrm{S}_{8}$ & $6.2 \pm 0.14$ & $1515 \pm 11.2$ & $33 \pm 2.2$ & $5800 \pm 56.6$ \\
\hline \multirow{8}{*}{$\begin{array}{l}\text { Peshawar } \\
\text { industrial } \\
\text { zone } \\
\text { Hayatabad }\end{array}$} & $\mathrm{S}_{1}$ & $3.2 \pm 0.1$ & $496 \pm 10.2$ & $33 \pm 2.4$ & $1296 \pm 41$ \\
\hline & $\mathrm{S}_{2}$ & $3.2 \pm 0.11$ & $500 \pm 7.5$ & $33 \pm 2.9$ & $1300 \pm 33.2$ \\
\hline & $\mathrm{S}_{3}$ & $6.1 \pm 0.1$ & $1040 \pm 9.1$ & $32.5 \pm 4.1$ & $3204 \pm 54.5$ \\
\hline & $\mathrm{S}_{4}$ & $6.3 \pm 0.13$ & $1100 \pm 9$ & $32 \pm 3.2$ & $3194 \pm 58.9$ \\
\hline & $\mathrm{S}_{5}$ & $5.9 \pm 0.15$ & $577 \pm 10.4$ & $32.4 \pm 2$ & $1700 \pm 29.4$ \\
\hline & $\mathrm{S}_{6}$ & $6.3 \pm 0.16$ & $673 \pm 9.4$ & $32 \pm 2.6$ & $1804 \pm 34.1$ \\
\hline & $\mathrm{S}_{7}$ & $6.7 \pm 0.14$ & $823 \pm 8.7$ & $32.4 \pm 3.1$ & $1776 \pm 34.6$ \\
\hline & $\mathrm{S}_{8}$ & $6.9 \pm 0.17$ & $880 \pm 10.6$ & $32.5 \pm 2.9$ & $1800 \pm 41.3$ \\
\hline
\end{tabular}

\subsection{Temperature}

Temperature of water is very much important with respect to survival of aquatic organisms. The effluents temperature depends on the chemical process carried out in the industry. The temperature values of various industrial effluents ranged from $32-33.2^{\circ} \mathrm{C}$ (Table 3). The highest value was found in the effluents of Utman Ghee Industry while the lowest in that of Attock Chemical Industry. The temperature values in all the effluents were within the permissible limits of NEQS (Table 2).

\subsection{Total dissolved solids (TDS)}

Various industrial effluents of the studied samples contained TDS in the range of 800$5800 \mathrm{mg} / \mathrm{L}$ as shown in (Table 3). In comparison to the NEQS, it can be seen that the TDS values in effluents of all the industries were within the permissible limits. The effluents with high TDS value may cause salinity problem if discharged to irrigation water. These results are in close ties with the earlier reports on TDS values of the industrial discharge from different areas of Pakistan [18]. 


\subsection{Heavy metals concentration}

Heavy metal concentrations in all the studied samples were in order of $\mathrm{Fe}>\mathrm{Pb}>\mathrm{Cu}>\mathrm{Mn}>\mathrm{Co}>\mathrm{Zn}>\mathrm{Cr}>\mathrm{Ni}(\mathrm{p}<0.05)$. The rresults showed that the levels in all the samples were below the permissible limits according to National Environmental Quality Standards (NEQS). The sources of Ni in the industrial effluents could be due to certain industries e.g. ghee and oil, chemicals, kitchen appliances, surgical instruments, steel alloys and automobiles batteries [19].

The concentration of $\mathrm{Cu}$ concentration was in the range of 0.102-0.260 ppm (Fig. 2). The industrial discharge of Gadoon Amazai had significantly higher concentration of this contaminant than Hayatabad $(\mathrm{p}<0.05)$. The presence of this metal in the studied samples could be a result of the possible contribution of metallic burden from the chemical process taking place inside the industries. It is however important to note that even very small quantity of some trace metals can be hazardous to life of plants and animals [4].

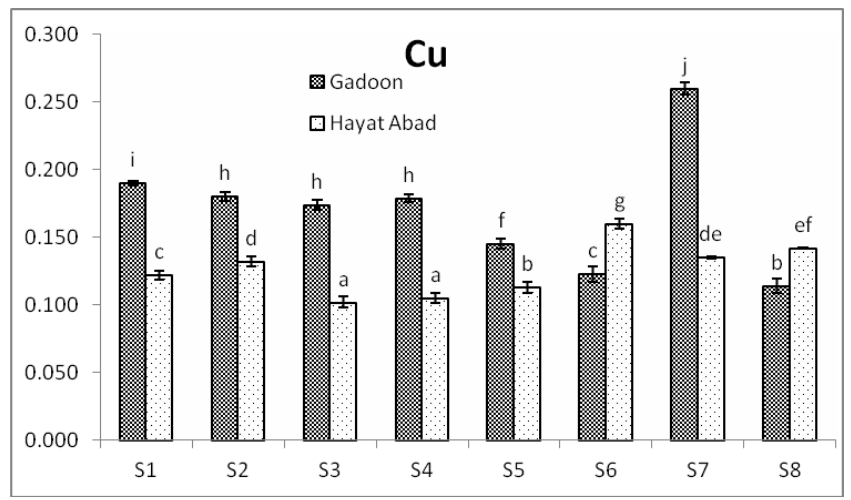

Fig. 2. Mean concentration of $\mathrm{Cu}$ in the discharge of various industries found in the industrial area of Gadoon Amazai, Sawabi and Hayatabad, Peshawar. Bars labeled with different alphabets are significantly different from each other (Duncan Multiple Range Test; $p<0.05$ ).

The range of Co concentration in the samples was 0.021-0.195 ppm (Fig. 3). The highest concentration of Co s found in the discharge from Utman Ghee Industry of Gdoon Amazai, while the lowest was in CSH Pharmaceutical (Pvt) of Hayatabad industrial area $(p<0.05)$. Co is beneficial for human's health because it is a part of vitamin $B_{12}$ [20], a major vitamin needed for general vigor and protectant against diseases [21-22]. Co is used to treat anaemia in pregnant women, because it stimulates the production of red blood cells [23]. The total daily intake of Co is variable and may be as much as $1 \mathrm{mg}$, but almost all will pass through the body unabsorbed, except that in vitamin $B_{12}$ [24]. Plants also need this metal in the form of colbalmin for the regulation of DNA synthesis during cell division [25]. 


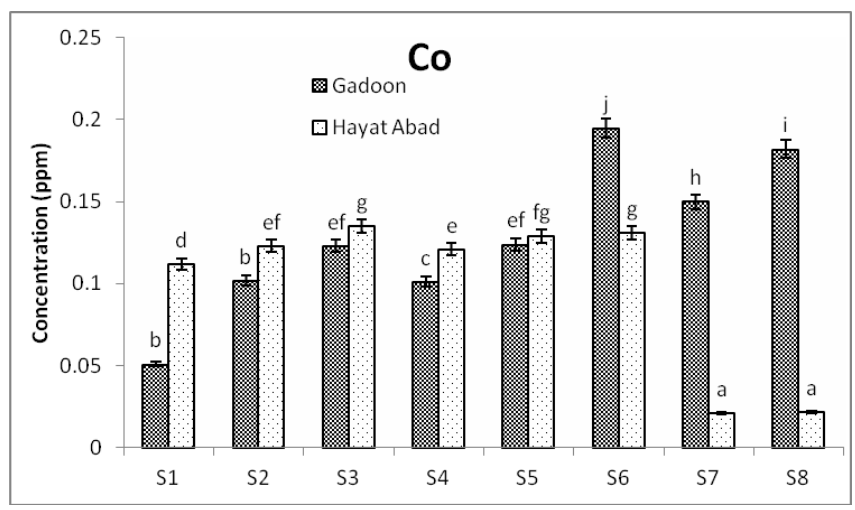

Fig. 3. Mean concentration of Co in the discharge of various industries found in the industrial area of Gadoon Amazai, Sawabi and Hayat Abad, Peshawar. Bars labeled with different alphabets are significantly different from each other (Duncan Multiple Range Test; $p<0.05$ ).

In spite of the beneficial effects of cobalt for humans, its high concentrations may be toxic to human health. Breathing in air containing too high concentrations of Co may lead to serious lung problems, such as asthma and pneumonia [25]. Several adverse effects of Co have been demonstrated in plants [26-27]. Plants grown on Co contaminated soil accumulate small amount of Co, especially in the edible parts such as fruits and seeds [28]. The uptake of Co by humans through eating the plants can cause health problems. The uptake of high concentrations of Co may include vomiting and nausea, vision problems, heart problems and thyroid damage. Health problems may also be caused by radiation of radioactive cobalt isotopes. This can cause sterility, hair loss, vomiting, bleeding, diarrhoea, coma and even death. This radiation is sometimes used for the treatment of cancer-patients to destroy tumours. The concentration of $\mathrm{Fe}$ in studied samples was found in the range of 0.191-0.330 ppm (Fig, 4). This metal was the heaviest contaminant, found to be significantly greater than other metals in the studied area ( $\mathrm{p}<$ 0.05). The maximum concentration of $\mathrm{Fe}$ was found in the industrial discharge of Hayatabad, Peshawar $(p<0.05)$. Fe is one of the dietary requirements for human beings, which is present in the human body approximately $4 \mathrm{~g}, 70 \%$ of which is present in red blood coloring agents. On daily bases approximately $7 \mathrm{mg}$ and $11 \mathrm{mg}$ of $\mathrm{Fe}$ is required for men and women respectively. The difference is due to menstrual cycles, which may cause the discharge of $\mathrm{Fe}$ from the body. The body absorbs approximately $25 \%$ of all Fe present in food. The deficiency of Fein the body may be compensated with the use of vitamin $\mathrm{C}$ tablets, as this vitamin reduces tertiary Fe to binary Fe. Fe is a central component of haemoglobin which transports oxygen from lungs to other body parts and $\mathrm{CO}_{2}$ back to the lungs [25]. 


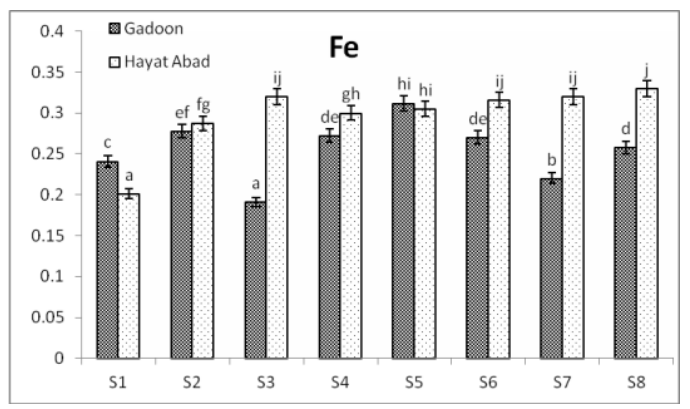

Fig. 4. Mean concentration of $\mathrm{Fe}$ in the discharge of various industries found in the industrial area of Gadoon Amazai, Sawabi and Hayatabad, Peshawar. Bars labeled with different alphabets are significantly different from each other (Duncan Multiple Range Test; $p<0.05$ ).

In spite of the importance in the body, exceeded amount of Fe may cause a number of problems such as bone marrow, damage of vital organs like pancreas, liver, spleen and the heart, when taken more than $200 \mathrm{ppm}$ in drinking water. Compounds of $\mathrm{Fe}$ may also have serious effect on health. Water soluble binary $\mathrm{Fe}$ compounds such as $\mathrm{FeCl}_{2}$ and $\mathrm{FeSO}_{4}$ may cause toxic effects, when the concentration exceeds $200 \mathrm{mg}$, and are mortal for adults upon doses of 10-50 g. A number of Fe chelates may be toxic, and the nerve toxin iron penta carbonyl is known for its strong toxic mechanism [29].

$\mathrm{Pb}$ was found second to $\mathrm{Fe}$ in terms of concentration (Fig. 5). Its concentration (0.117$0.330 \mathrm{ppm})$ in the industrial effluent though less than the permissible limit of NEQS $(0.500 \mathrm{ppm})$, may accumulate in vegetables and crops grown on the discharge, above its permissible limits. The highest concentration of $\mathrm{Pb}$ was found in the effluents of Khyber Group of Precast Hayatabad and lowest in that of Amrat Cola, Pak Mineral Water Industry Gadoon ( $<<0.05)$. These findings imply that consumption of the polluted water by animals or human beings could be hazardous to their health. Soil contaminated by these effluents may produce unhealthy food, as heavy metals can enter the food chain and thus be consumed by human beings [30]. Similarly, $\mathrm{Pb}$ can displace $\mathrm{Ca}$ in bone to form softer denser spots. It also inactivates cysteine containing enzymes, allowing more internal toxicity from free radicals, chemicals and other heavy metals [31].

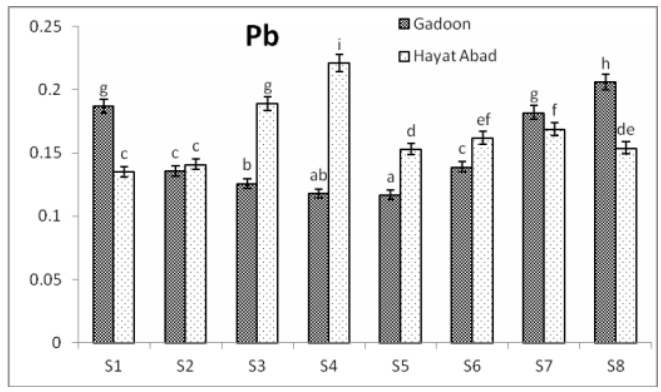

Fig. 5. Mean concentration of $\mathrm{Pb}$ in the discharge of various industries found in the industrial area of Gadoon Amazai, Sawabi and Hayat Abad, Peshawar. Bars labeled with different alphabets are significantly different from each other (Duncan Multiple Range Test; $p<0.05$ ) 
Recent studies on $\mathrm{Pb}$ have shown that adverse health effects occur at lower levels of exposure to $\mathrm{Pb}$ than previously thought. Even at low level of exposure to $\mathrm{Pb}$, the main health effects observed are the nervous system, intellectual development of infants and children. Infants and toddlers are particularly vulnerable to the harmful effects of $\mathrm{Pb}$ because they are undergoing a period of rapid development. Furthermore, their growing bodies absorb $\mathrm{Pb}$ more easily and excrete $\mathrm{Pb}$ less efficiently than adults. In addition, infants and young children are more likely to ingest $\mathrm{Pb}$ because of their natural habit of putting objects into their mouths. $\mathrm{Pb}$ once entered to the body circulate in the blood and either accommodate in bone or eliminate from the body, mostly in urine. $\mathrm{Pb}$ can stay in the body for over 30 years following exposure [29].

Health effects associated with exposure to high levels of $\mathrm{Pb}$ include vomiting, diarrhea, convulsions, coma or even death [30]. $\mathrm{Pb}$ is more damaging in children up to the age of six years. Children usually grow at a very fast rate, grow bones, develop stronger muscles and creat many connections in their brain. When $\mathrm{Pb}$ instead of essential nutrients is available to the body, permanent health problems can occur like learning disabilities (decreased IQ), behavior issues, nervous system damage, speech and language deficiency, decreased muscle and bone growth and kidney damage [31].

In case of high levels of $\mathrm{Pb}$, life threatening, unconsciousness, and even death can occur. The most common effects of $\mathrm{Pb}$ exposure to adults may cause increased chances of illness during pregnancy, harm to a fetus including brain damage or death, fertility problems in men and women, high blood pressure, digestive issues, nerve disorders, memory problems and muscle and joint pain [30].

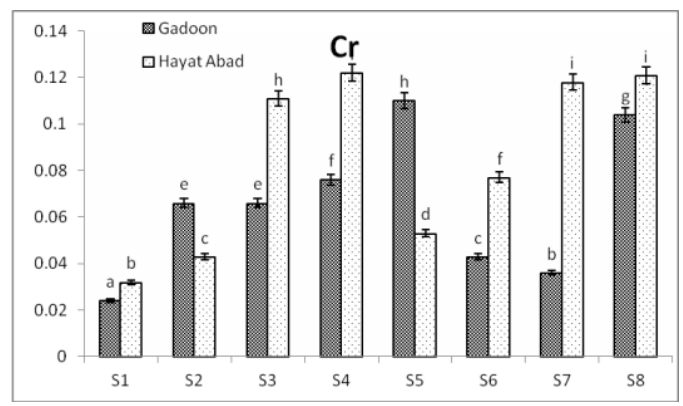

Fig. 6. Mean concentration of $\mathrm{Cr}$ in the discharge of various industries found in the industrial area of Gadoon Amazai, Sawabi and Hayatabad, Peshawar. Bars labeled with different alphabets are significantly different from each other (Duncan Multiple Range Test; $p<0.05$ ).

The concentration of $\mathrm{Cr}$ was the second least metal in the samples, varied between 0.024-0.121 ppm in the industrial discharge, a concentration range lower than that of permissible limit (1.0 ppm) of NEQS (Fig. 6). The highest concentration of $\mathrm{Cr}$ was found in CSH Pharmaceutical (Pvt), while the lowest one was found in Attock Chemical Industry $(p<0.05)$. The reported amount of this metal in human body is approximately 
$0.03 \mathrm{ppm}$ [32]. The daily intake of $\mathrm{Cr}$ in normal human from different sources is approximately $15-200 \mu \mathrm{g}$, which may sometimes reach up to $1 \mathrm{mg}$ [33]. Trivalent $\mathrm{Cr}$ is an essential trace element for humans, which along with insulin removes glucose from blood, and plays a vital role in fat metabolism. Deficiency of $\mathrm{Cr}$ may enhance the symptoms of diabetes. Cr (III) toxicity is unlikely, at least when it is taken up through food and drinking water [34]. Cr in hexavalent is known for its negative health and environmental impact, and its extreme toxicity. Its effects may cause allergy, asthma and is carcinogenic, which is 1000 times more toxic than trivalent $\mathrm{Cr}$. Health effects related to hexavalent $\mathrm{Cr}$ may include diarrhea, stomach and intestinal bleedings, cramps, and liver and kidney damage. Hexavalent $\mathrm{Cr}$ is mutagenic. Toxic effects may be passed on to children through the placenta [25].

$\mathrm{Mn}$ is one of those trace elements, which are not only necessary in small quantity for human survival, but also toxic at high concentrations [8]. The concentration of $\mathrm{Mn}$ in the studied samples was found in the range of 0.053-0.234 ppm (Fig. 7) which was well below the safe limit of this metal $(1.5 \mathrm{ppm})$ set by NEQS. Its amount was significantly higher in the discharged by Utman Ghee Industry than all other samples $(\mathrm{p}<0.05)$. Lowest amount of Mn was recorded in the effluent released by AAj Textile Mill of Gadoon Industrial Area. The uptake of Mn by humans mainly takes place through food, such as spinach, tea and herbs. The foodstuffs containing the highest concentration of $\mathrm{Mn}$ are grains, rice, soya beans, eggs, nuts, olive oil, green beans and oysters [18]. After absorption in the human body, manganese finds its way to liver, kidneys, pancreas and endocrine glands. Excess of Mn also affects respiratory tract and brain. It may also cause Parkinson, lung embolism and bronchitis. As $\mathrm{Mn}$ is an essential element for human health, its shortage can cause severe health effects [29].

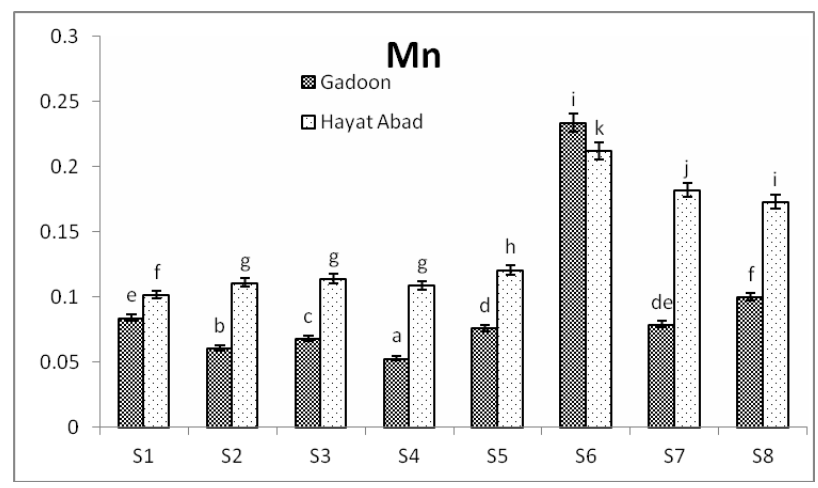

Fig. 7. Mean concentration of $\mathrm{Mn}$ in the discharge of various industries found in the industrial area of Gadoon Amazai, Sawabi and Hayat Abad, Peshawar. Bars labeled with different alphabets are significantly different from each other (Duncan Multiple Range Test; $p<0.05$ ). 
The range of concentration for $\mathrm{Zn}$ in the selected samples was 0.090-0.165 ppm (Fig. 8), which was found below NEQS limits (Table 3). Zn, like Mn, in trace quantity (15 mg per day) is essential for human health and its deficiency may cause loss of appetite, decreased sense of taste and smell, slow healing of wound and even birth defects [5-7]. Concentration of $\mathrm{Zn}$ above the recommended limits may also be harmful, causing prominent health problems, like stomach cramps, skin irritations, vomiting, nausea and anemia [35]. Very high concentration of $\mathrm{Zn}$ may damage pancreas and disturb the protein metabolism, causing arteriosclerosis. $\mathrm{Zn}$ may be a danger to unborn and new-born children, when exposed through blood or milk of their mothers. The daily uptake of $\mathrm{Zn}$ greater than $25 \mathrm{mg}$ may cause anemia and $\mathrm{Cu}$ deficiency [14].

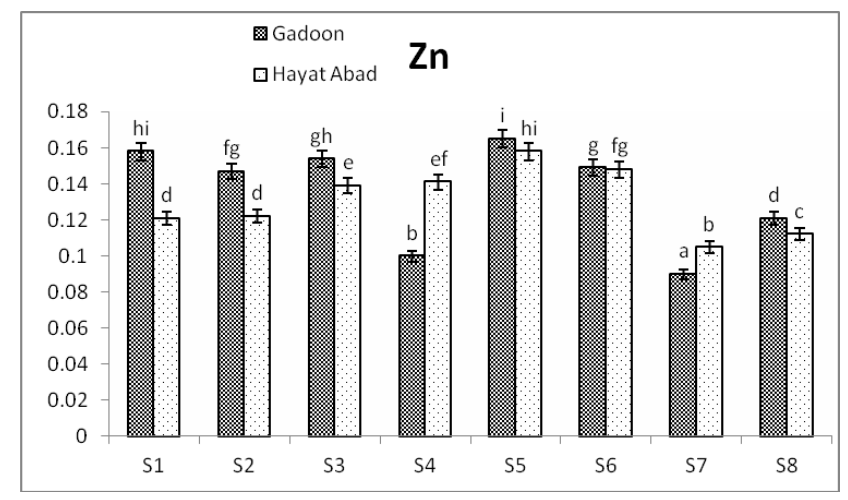

Fig. 8. Mean concentration of $\mathrm{Zn}$ in the discharge of various industries found in the industrial area of Gadoon Amazai, Sawabi and Hayat Abad, Peshawar. Bars labeled with different alphabets are significantly different from each other (Duncan Multiple Range Test; $p<0.05$ ).

The concentration of $\mathrm{Ni}$ was the least and, varied from 0.019-0.074 ppm in concentration, found in the studied industrial effluents as clear from Fig. 9. Its concentration was greatest in the effluents of Attock Chemical Industry $(0.074 \mathrm{ppm})$ than the entire range of samples $(p<0.05)$. The lowest amount was detected in the discharge of M Ali Textile Mill $(p<0.05)$. This was within the permissible limits (NEQS 2000). Ni like other heavy metals, is very toxic even in a trace quantity. $\mathrm{Ni}$ in metallic form as well as most of its compounds has negative effects on human health. Contact with $\mathrm{Ni}$ compounds can cause a variety of adverse effects on human health, such as Ni allergy in the form of contact dermatitis, lung fibrosis, cardiovascular and kidney diseases and cancer of the respiratory tract [36]. From long-term exposure to relatively low concentrations of pollutants may result in chronic non cancer health effects. Acute health effects generally result from short-term exposure to high concentrations of pollutants and they manifest as a variety of clinical symptoms (nausea, vomiting, abdominal discomfort, diarrhea, visual disturbance, headache, giddiness, and cough) [37]. 


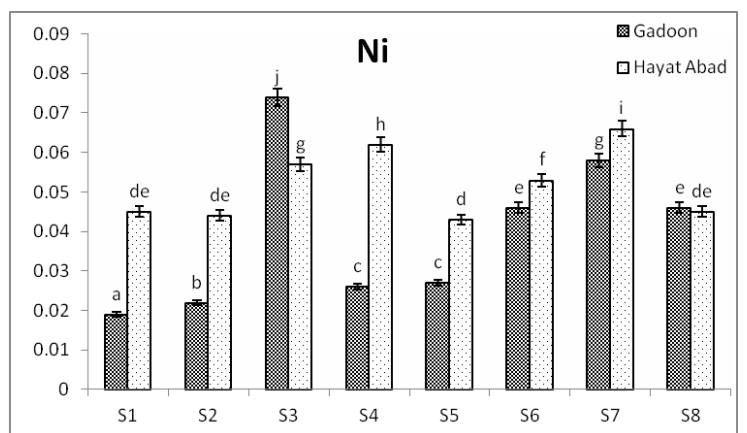

Fig. 9. Mean concentration of $\mathrm{Ni}$ in the discharge of various industries found in the industrial area of Gadoon Amazai, Sawabi and Hayat Abad, Peshawar. Bars labeled with different alphabets are significantly different from each other (Duncan Multiple Range Test; $p<0.05$ )

\section{Conclusion}

All the industrial effluents studied in this work contain all the physiochemical parameters within the permissible range. However some of them have low PH which is more acidic and toxic for plants, animals and human beings. Heavy metal concentrations in the studied industrial effluents are within the permissible range, which can be used for the irrigation purposes. However their long use may create some diseases in human beings living in these areas. It is therefore suggested that the industrial effluent of all the industries should be treated before being discharged for irrigation purpose in order to reduce the chances of diseases in the human beings caused due to heavy metals.

\section{References}

1. L. Grobelny, W. A. Pisarski, J. Pisarska., R. Lisiecki, and W. Ryba-Romanowski, J. Rare Earths 29, 1192 (2011). http://dx.doi.org/10.1016/S1002-0721(10)60624-2

2. S. O Fakayode and P. C. Onianwa, Environ. Geol. 43, 145 (2002). http://dx.doi.org/10.1007/s00254-002-0633-9

3. O. Phiri, P. Mumba, B. H. Z. Moyo, and W. Kadewa, J. Environ. Sci. Technol. 2, 237 (2005). http://dx.doi.org/10.1007/BF03325882

4. M. A. Hashim, S. Mukhopadhyay, J. N. Sahu, and B. Sengupta, J. Environ. Management 92, 2355 (2011). http://dx.doi.org/10.1016/j.jenvman.2011.06.009

5. K. Ahmed, and A. I. Tanlo, J. Arid. Agri.10, 89 (2000).

6. J. Lars, British Medical Bull. 68, 167 (2003). http://dx.doi.org/10.1093/bmb/ldg032

7. S. Ali, H. Teruo, J. Fakher, and B. Samir, J. Environ. Management 93, 245 (2012). http://dx.doi.org/10.1016/j.jenvman.2011.08.014

8. R Petrus and J. K. Warchol, Water Res. 39819 (2005). http://dx.doi.org/10.1016/j.watres.2004.12.003

9. M R.Bruins, S. Kapil, and F. W. Oehme, Ecotoxicol. Environ. Safety 45, 198 (2000). http://dx.doi.org/10.1006/eesa.1999.1860 


\section{Heavy Metals Contamination}

10. H. Lokeshwari and G. T. Chandrappa, Current Sci. 91, 584 (2006).

11. M. M. Ashraf and J. Tariq, J. Chem. Soc. Pakistan 17, 204 (1995).

12. B. F. Quinn and. J. K. Syres, J. Agricul. Res. 21, 435 (1978). http://dx.doi.org/10.1080/00288233.1978.10427431

13. NEQS. National Environmental Quality Standards for Municipal and Liquid Industrial Effluents (New York, 2000) pp 472.

14. E. G.Riodan, V. A. Dodd, H. Tunney, and G. A. Fleming, Ireland J. Agricul. Res. 25, 239 (1983)

15. B. C. Vijaya, K. Kumar, and G. Nagendrappa, E-J. Chem. 7, 349 (2010). http://dx.doi.org/10.1155/2010/671871

16. P. S. Dominguez-Salas, E. Cox, A. M. Prentice, B. J. Hennig and S. E. Moore, Proceed. Nutrit. Soc. 1, 1 (2011).

17. E. S. Moreira, N. E. Brasch, and J. Yun, Free Radical Biology and Medicine 51, 876 (2011). http://dx.doi.org/10.1016/j.freeradbiomed.2011.05.034

18. H. F. Li, C. Gray, C. Mico, F. J. Zhao, and S. P. McGrath, Chemosphere 75, 979 (2009).

19. P. C. Nagajyoti, K. D. Lee, and T. V. M. Sreekanth, Environ. Chem. Lett. 8, 199 (2001).

20. D. Luo, H. Zheng, Y. Chen, G. Wang, and D. Fenghua, J. Environ. Management 91, 2248 (2010). http://dx.doi.org/10.1016/j.jenvman.2010.06.001

21. C. S. Birch, N. E. Brasch, A. McCaddon, and J. H. H. Williams, Free Radical Biology and Medicine 47, 184 (2009). http://dx.doi.org/10.1016/j.freeradbiomed.2009.04.023

22. D. Ekinci, S. B. Ceyhun, E. Aksakal, and O. Erdoan, Toxicol. Pharmacol. 153, 336 (2011).

23. D. Joksimovic, I. Tomic, A. R. Stankovic, M. Jovic, and S. Stankovic, Food Chem. 127, 632 (2011). http://dx.doi.org/10.1016/j.foodchem.2011.01.057

24. A. G. Smith, M. T. Croft, M. Moulin, and M. E. Webb, Curr. Opin. Plant Bio. 10, 266 (2007). http://dx.doi.org/10.1016/j.pbi.2007.04.009

25. D. C. Aleksandra, and B. Urszula, J. Elementology 13, 685 (2008).

26. F. A. Jan, M. Ishaq, S. Khan, M. Shakirullah, S. M. Asim, and I. Ahmad, J. Environ. Sci. 23, 2069 (2011).

27. M. Tariq, M. Ali, and Z. Shah, Soil Environment 25, 64 (2006).

28. L. S. Underwood, New England J. Medicine 322, 83 (2002).

29. H. Xiaoshuai, W. Huoyan, Z. Jianmin, M. Chengling, D. Changwen, and C. Xiaoqin, Environ. Pollut. 157, 2542 (2009). http://dx.doi.org/10.1016/j.envpol.2009.03.002

30. Y. Yong, Z. F. Suo, L. H. Fen, and R. F. Jiang, J. Environ. Management 90, 1117 (2009). http://dx.doi.org/10.1016/j.jenvman.2008.05.004

31. D. B. Mcgregor, R. A. Baan, C. Partensky, J. M. Rice, and J. D. Wilbourn, Eur. J. Cancer 36, 307 (2000). http://dx.doi.org/10.1016/S0959-8049(99)00312-3

32. K. Schwaiger, K. Helmke, C. S. Hölzel, and J. Bauer, Environ. Health Res. 21, 161(2011). http://dx.doi.org/10.1080/09603123.2010.515672

33. N. McCallum, B. Berger-Bächi, and M. M. Senn, Int. J. Med. Microbiol. 300, 118 (2010). http://dx.doi.org/10.1016/j.ijmm.2009.08.015

34. S. Khan, Q. Cao, Y. M. Zheng, Y. Z. Huang, Y. G. Zhu, Environment Pollut.17 (2007).

35. N. Zheng, Q. C. Wang, D. M. Zheng, Sci. Total Environment 38, 381 (2007).

36. S. K. Seilkop and A. R. Oller, Regulatory Toxicol. Pharmacol. 37, 173 (2003). http://dx.doi.org/10.1016/S0273-2300(02)00029-6

37. J. J. Fu, Q. F. Zhou, J. M. Liu, W. Liu, T. Wang, Q. H. Zhang, and G. B. Jiang, Chemosphere, 71, 1269 (2008). http://dx.doi.org/10.1016/j.chemosphere.2007.11.065 